\title{
Interactions among the branched-chain amino acids and their effects on methionine utilization in growing pigs: effects on nitrogen retention and amino acid utilization
}

\author{
Stefan Langer* and Malcolm F. Fuller $\dagger$ \\ Rowett Research Institute, Greenburn Road, Bucksburn, Aberdeen AB21 9SB, UK
}

(Received 2 June 1999 - Accepted 22 June 1999)

\begin{abstract}
An experiment was conducted to investigate the effects of branched-chain amino acid (BCAA) interactions on their utilization by growing pigs and the effects of excessive amounts of BCAA (leucine, isoleucine, valine) on the utilization of methionine. A semipurified diet containing $100 \mathrm{~g}$ crude protein $/ \mathrm{kg}$ with a balanced amino acid pattern was prepared using casein supplemented with free amino acids. Three further diets were made by reducing the concentration of methionine + cyst(e)ine, valine or isoleucine by $20 \%$. Each of these four diets was then supplemented with leucine $(50 \%$ excess) or a mixture of BCAA $(50 \%$ excess of each but excluding the limiting amino acid). All diets were isoenergetic and were made isonitrogenous by replacement of glutamic and aspartic acids. The twelve diets were given to twenty-four growing pigs $(30-40 \mathrm{~kg})$ in three periods according to a randomized block design. Each period lasted $8 \mathrm{~d}$ and $\mathrm{N}$ retention was measured during the last $5 \mathrm{~d}$ of each period. Reducing dietary methionine, valine or isoleucine reduced the utilization of $\mathrm{N}$ ( $\mathrm{N}$ retained/N digested) by approximately $20 \%$ $(P<0.05)$. Adding leucine to the isoleucine-limiting diet decreased the utilization of $\mathrm{N}$ by $9 \%$ $(P<0.05)$. This was reversed by simultaneous addition of valine. Excess leucine in a valinedeficient diet did not significantly reduce $\mathrm{N}$ utilization. In methionine-limiting diets an excess of either leucine alone or of all three BCAA increased the utilization of $\mathrm{N}$ by $8 \%(P<0.05)$.
\end{abstract}

Branched-chain amino acids: Methionine: Amino acid utilization

Interactions amongst the branched-chain amino acids (BCAA) have been investigated mainly in rats (Harper et al. 1970, 1983; Block, 1989) and poultry (D'Mello \& Lewis, 1970; Calvert et al. 1982). However, in most experiments relatively large excesses of BCAA were used. Leucine appears to be the most potent among the BCAA and excess dietary leucine has been shown to reduce the concentrations of valine, isoleucine and their $\alpha$-keto acids in plasma and tissues (Tannous et al. 1966; D’Mello \& Lewis, 1970; Block \& Harper, 1991) and to enhance the activity of branched-chain keto-acid dehydrogenase (EC 1.2.4.4; $\mathrm{BCKDH}$ ) in various tissues (Frick et al. 1981; Block et al. 1985; Aftring et al. 1986). The stimulation of BCAA catabolism by dietary leucine excess could account for the depletion of the plasma pools of valine, isoleucine, $\alpha$ ketoisovaleric acid and $\alpha$-keto- $\beta$-methyl-n-valeric acid, which appears to depress food intake and growth (Harper et al. 1983; Block, 1989). Studies by Calvert et al. (1982) in chicks and by Block \& Harper (1984) in rats showed that a relatively large excess of leucine $(>38 \mathrm{~g} / \mathrm{kg}$ diet $)$ increased the oxidation of isoleucine and valine. Increased oxidation would affect the utilization of these amino acids and might consequently affect animal performance when one of the two amino acids is limiting for growth. However, BCAA concentrations in practical diets do not normally exceed twice the requirement $(15 \mathrm{~g} / \mathrm{kg})$; hence, from the practical point of view, it seems to be more important to investigate how moderate BCAA excesses could affect animal performance.

The importance of interactions among the BCAA in the pig is not well-established. Oestemer et al. (1973) found that increasing dietary leucine concentration from $7 \cdot 0$ to $10.2 \mathrm{~g} / \mathrm{kg}$ diet in diets marginally deficient in isoleucine reduced the concentrations of valine and isoleucine in plasma. However, the effects on the efficiencies of food and protein conversion were not consistent. Henry et al. (1976), using a similar leucine excess, confirmed the effects on plasma valine and isoleucine concentrations but did not show any effect on growth performance.

An increase in dietary leucine from 13.4 to $20.4 \mathrm{~g} / \mathrm{kg}$ in

\footnotetext{
Abbreviations: BCAA, branched-chain amino acids; BCKDH, branched-chain keto-acid dehydrogenase.

* Present address: Agribrands Europe Espana, Aribau 197-199, escalera 1, Planta 3, puertas 1 y 2 , 08021 Barcelona, Spain.

$\dagger$ Corresponding author: Dr Malcolm Fuller, fax +44 (0)1224 716687, email aw@ rri.sari.ac.uk
} 
diets marginally deficient in isoleucine $(3.8 \mathrm{~g} / \mathrm{kg})$ reduced growth performance and plasma valine and isoleucine concentrations (Taylor et al. 1984). These authors concluded that this might have resulted from a reduction in isoleucine availability caused by the higher dietary leucine concentration.

The catabolism of methionine is linked with that of the BCAA via BCKDH (Benevenga, 1984). In vitro results from incubations of rat liver suggest that methionine decarboxylation is affected by branched-chain keto acids (Livesey, 1981). However, whether BCAA excesses affect methionine catabolism in vivo is not known.

The present experiment was conducted to investigate the importance and mechanism of amino acid interactions in the growing pig, especially the regulatory effects amongst the BCAA and methionine. The aims of the experiment were, first, to confirm that BCAA interactions affect protein utilization in pigs even at moderate levels of excess and, second, to see if, in vivo, methionine utilization is altered by moderate excesses of BCAA. These results were reported briefly to the Nutrition Society (Langer \& Fuller, 1994).

\section{Materials and methods}

\section{Animals}

Twenty-four Cotswold crossbred gilts, 10 weeks of age, with an average starting weight of 29.6 (SD 2.62) $\mathrm{kg}$ were used in this experiment. Their mean finishing weight was 39.1 (SD 3.54) kg. All management and experimental procedures in this study were carried out in strict accordance with the requirements of the UK Animals (Scientific Procedures) Act 1986 by staff licensed under this Act to carry out such procedures.

\section{Diets and feeding}

The pigs were given a low $\mathrm{N}$ intake to ensure that differences in response between balanced and unbalanced diets would be expressed. Four isoenergetic and isonitrogenous diets based on casein and synthetic amino acids were used (Tables 1 and 2), either with an optimally balanced amino acid pattern (Wang \& Fuller, 1989, 1990; histidine content $(2.5 \mathrm{~g} / 16 \mathrm{~g} \mathrm{~N})$ was taken from Wang \& Fuller, 1990) or made limiting ( $80 \%$ of requirement) in methionine, valine or isoleucine. Each of these diets was given alone (treatments $1-4)$, or supplemented with leucine $(50 \%$ excess; treatments 5-8), or supplemented with leucine (50\% excess) together with the other non-limiting BCAA (treatments 9-12) (i.e. the valine-deficient diet had 50\% excess isoleucine, the isoleucine-deficient diet had $50 \%$ excess valine, and the control and methionine-deficient diets had $50 \%$ excess of each). This gave a total of twelve diets. Valine, isoleucine, leucine and methionine were added or removed at the expense of aspartic acid and monosodium glutamate.

The diets were given at the rate of $80 \mathrm{~g} / \mathrm{kg}$ body weight ${ }^{0.75}$ per d which was calculated to supply about $1.25 \mathrm{~g} \mathrm{~N} / \mathrm{kg}$ body weight ${ }^{0.75}$. The animals received their diets twice daily at 08.30 and 15.30 hours. Water was freely available by nipple drinkers and was also added to the diets during feeding to reduce spillage.

\section{Experimental design}

After a $7 \mathrm{~d}$ adaptation period on the optimally balanced control diet the twelve diets were given in three periods according to a randomized block design (Table 3). Each period lasted $8 \mathrm{~d}$, made up of $3 \mathrm{~d}$ adjustment and $5 \mathrm{~d}$ collection. Each animal received three of the twelve diets and none of the animals had the same diet twice. Throughout the experiment the animals were kept individually in metabolism cages at a room temperature of $22-24^{\circ}$.

\section{Sample collection, storage and chemical analysis}

During the last $4 \mathrm{~d}$ of each period urine was collected into $200 \mathrm{ml} 2 \mathrm{M}-\mathrm{H}_{2} \mathrm{SO}_{4}$ using bladder catheters introduced as described by Fuller et al. (1979). Two successive $24 \mathrm{~h}$ collections were pooled. Faeces were collected during the last $5 \mathrm{~d}$ of each period and preserved in $2 \mathrm{M}^{-} \mathrm{H}_{2} \mathrm{SO}_{4}$ (approximately $500 \mathrm{ml} / \mathrm{d}$ ). After homogenization a portion was taken for analysis. Urine and faeces samples were stored at $-20^{\circ}$ and diet samples were stored at $+4^{\circ}$. Diets, urine and faeces were analysed for $\mathrm{N}$ by the macro-Kjeldahl procedure (Davidson et al. 1970). Amino acid concentrations (except methionine, cyst(e)ine and tryptophan) were determined by ion-exchange chromatography. Concentrations of methionine, cyst(e)ine and tryptophan in the diets were analysed by Degussa AG (Hanau, Germany). Methionine and cyst(e)ine concentrations were determined after oxidation with performic acid as described by Bech-Andersen et al. (1990) and tryptophan concentration according to Naumann \& Bassler (1993). Amino acid concentrations were calculated using the molecular mass of the free amino acid.

\section{Statistical analysis}

A crossover design was used, with twelve treatments applied over three periods to twenty-four animals, each

Table 1. Experimental design*

\begin{tabular}{lccc}
\hline \multirow{2}{*}{$\begin{array}{l}\text { Limiting } \\
\text { amino acid }\end{array}$} & \multicolumn{3}{c}{ Amino acid as \% of requirement } \\
\cline { 2 - 4 } & No excess & Leucine & \multicolumn{1}{c}{ BCAA } \\
\hline None (control) & $100($ T1) & $150($ T5) & Leucine 150 + isoleucine 150 + valine 150 (T9) \\
Methionine & $80($ T2) & $150($ T6) & Leucine 150 + isoleucine 150 + valine 150 (T10) \\
Vailne & $80($ T3) & $150($ T7) & Leucine 150 + isoleucine 150 (T11) \\
Isoleucine & $80($ T4) & $150($ T8) & Leucine 150 + valine 150 (T12) \\
\hline
\end{tabular}

BCAA, branched-chain amino acids; $T$, treatment.

${ }^{*}$ For further details, see above. 
Table 2. Ingredient composition and amino acid pattern of the control diet (air-dry basis)

\begin{tabular}{|c|c|c|c|c|}
\hline \multicolumn{2}{|c|}{ Control diet } & \multirow[b]{2}{*}{ Amino acid } & \multicolumn{2}{|c|}{ Concentration (g/16g N) } \\
\hline Ingredient & $\mathrm{g} / \mathrm{kg}$ & & Calculated & Measured \\
\hline Casein* & 59.00 & Aspartic acid & $26 \cdot 77$ & $26 \cdot 78$ \\
\hline Maize starch & 323.85 & Threonine & $4 \cdot 70$ & 4.78 \\
\hline Glucose & 238.67 & Serine & $2 \cdot 82$ & 3.41 \\
\hline Sugar & $150 \cdot 00$ & Glutamic acid & $38 \cdot 11$ & 37.05 \\
\hline Powdered cellulose & 65.00 & Proline & $6 \cdot 28$ & 6.54 \\
\hline Oil (vegetable) & $40 \cdot 00$ & Glycine & 3.32 & 3.53 \\
\hline Mineral-vitamin mix $†$ & $53 \cdot 13$ & Alanine & $2 \cdot 33$ & 2.47 \\
\hline Aspartic acid & 22.05 & Valine & 4.90 & 4.92 \\
\hline Threonine & 2.00 & Cyst(e)ine & 1.64 & 1.58 \\
\hline Monosodium glutamate & 28.05 & Methionine & $2 \cdot 46$ & $2 \cdot 79$ \\
\hline Alanine & 0.70 & Isoleucine & 3.90 & $3 \cdot 70$ \\
\hline Glycine & $2 \cdot 20$ & Leucine & $7 \cdot 20$ & 6.95 \\
\hline Valine & 1.22 & Tyrosine & 3.90 & 3.85 \\
\hline Cyst(e)ine & 1.39 & Phenylalanine & 3.90 & 3.92 \\
\hline Methionine & 0.96 & Lysine & $6 \cdot 50$ & $6 \cdot 61$ \\
\hline Isoleucine & 0.98 & Histidine & $2.50 \ddagger$ & $2 \cdot 68$ \\
\hline Leucine & 2.03 & Arginine & $4 \cdot 30$ & $4 \cdot 13$ \\
\hline Tyrosine & 0.97 & Tryptophan & 1.20 & 1.05 \\
\hline Phenylalanine & 1.05 & & & \\
\hline Lysine-HCl & $2 \cdot 62$ & & & \\
\hline Histidine- $\mathrm{HCl}$ & 1.20 & Digestible energy (MJ/kg) & $17 \cdot 16$ & ND \\
\hline Arginine- $\mathrm{HCl}$ & $2 \cdot 41$ & $N(g / k g)$ & $15 \cdot 53$ & $16 \cdot 29$ \\
\hline Tryptophan & 0.53 & & & \\
\hline
\end{tabular}

ND, not determined

* Casein contained: $\mathrm{N}$ (g/kg) 139.87; amino acids (g/16 g N): Asp 7.62, Thr 4.33, Ser 5.30, Glu 24.42, Pro 11.82, Gly 1.99, Ala 3.03, Val 6.83, Cys 0.35, Met 2.70, Ile 5.44, Leu 9.40, Tyr 5.41, Phe 5.20, Lys 8.20, His 2.76, Arg 4.15, Trp 1.20. † Mineral and vitamin mixture contained $(\mathrm{g} / \mathrm{kg})$ : Pigvite 12 (Norvite-Feed Supplements, Aberdeenshire, UK) 2.3, dicalcium phosphate (48\%) 37, potassium bicarbonate 9.4 , magnesium oxide 0.6 , Vitamin $\mathrm{B}_{12}$ Customix (NorviteFeed Supplements) $1 \cdot 4$, choline chloride $(50 \%) 2 \cdot 1$, and $(\mathrm{mg} / \mathrm{kg})$ : iron sulfate 88.8 , nicotinic acid $8 \cdot 4$, pteroylmonoglutamic acid 1.9 , biotin (2\%) $2 \cdot 3$, pantothenic acid $6 \cdot 3$, pyridoxine $2 \cdot 5$, thiamin 1.9 , riboflavin 0.8 , inositol 138.8 , ascorbic acid 11.1.

‡From Wang \& Fuller (1990).

animal receiving three treatments and each treatment being allocated to two animals in any one period. Groups of four similar animals (blocks) were chosen to form complete replicates, there being six of these. The allocation of treatments to animals over three periods is given in Table 3 . The data were analysed using a generalized linear model (GENSTAT 5.2; Rothamsted Experimental Station, Harpenden, Herts., UK) with terms for animal, treatment and period plus a covariate for $\mathrm{N}$ intake $(23+11+2+1=37$ d.f. $)$. No allowance was made for carry-over effects and there was no recovery of 'inter-block' information.

\section{Results}

All animals grew satisfactorily (although slowly as a consequence of the low-N diet) and there were only a few food refusals. These were dried and food intake and $\mathrm{N}$ intake were corrected on a DM basis. Two animals had blocked urinary catheters in period 1 , but recovered satisfactorily to continue the experiment. Data from these two animals (for period 1 only) were excluded from the analysis. The calculated amino acid pattern of all diets was confirmed by amino acid analysis. The pattern in the control diet is given in Table 2.

$\mathrm{N}$ retention was calculated as $\mathrm{N}$ intake - (urinary $\mathrm{N}+$ faecal $\mathrm{N}$ ); $\mathrm{N}$ utilization (Table 4) was expressed as $\mathrm{N}$ retained: $\mathrm{N}$ digested. $\mathrm{N}$ digested was calculated as $\mathrm{N}$ intake-faecal $\mathrm{N}$.
Table 3. Allocation of treatments (T1-T12) to animals (A1-A24) over three periods (P1-P3)

\begin{tabular}{lrrr}
\hline & & Period & \\
\cline { 2 - 4 } Animal & P1 & P2 & P3 \\
\hline A1 & T1 & T5 & T9 \\
A2 & T2 & T6 & T10 \\
A3 & T3 & T7 & T11 \\
A4 & T4 & T8 & T12 \\
A5 & T5 & T10 & T4 \\
A6 & T6 & T11 & T1 \\
A7 & T7 & T12 & T2 \\
A8 & T8 & T9 & T3 \\
A9 & T9 & T4 & T6 \\
A10 & T10 & T1 & T7 \\
A11 & T11 & T2 & T8 \\
A12 & T12 & T3 & T5 \\
A13 & T1 & T6 & T12 \\
A14 & T2 & T9 & T9 \\
A15 & T3 & T8 & T10 \\
A16 & T4 & T5 & T11 \\
A17 & T5 & T11 & T2 \\
A18 & T6 & T12 & T3 \\
A19 & T7 & T9 & T4 \\
A20 & T8 & T10 & T1 \\
A21 & T9 & T3 & T5 \\
A22 & T10 & T4 & T6 \\
A23 & T11 & T1 & T7 \\
A24 & T12 & T2 & T8 \\
\hline
\end{tabular}


Table 4. Influence of leucine or branched-chain amino acid (BCAA) excesses on nitrogen utilization (nitrogen retained:nitrogen digested $^{*}$ ) in diets limiting in methionine, isoleucine or valine (Mean values with their standard errors for six pigs)

\begin{tabular}{|c|c|c|c|c|c|c|}
\hline \multirow{3}{*}{$\begin{array}{l}\text { Limiting } \\
\text { amino acid }\end{array}$} & \multicolumn{6}{|c|}{ Amino acid excess } \\
\hline & \multicolumn{2}{|c|}{ No excess } & \multicolumn{2}{|c|}{ Leucine } & \multicolumn{2}{|c|}{ BCAA† } \\
\hline & Mean & SE & Mean & SE & Mean & SE \\
\hline None & $0.77^{\mathrm{a}}$ & 0.015 & $0.75^{\mathrm{a}}$ & 0.015 & $0.76^{\mathrm{a}}$ & 0.014 \\
\hline Methionine & $0.67^{b}$ & 0.014 & $0.72^{a b}$ & 0.016 & $0.72^{\mathrm{ab}}$ & 0.016 \\
\hline Valine & $0.68^{b}$ & 0.014 & $0.66^{b}$ & 0.015 & $0.70^{\mathrm{b}}$ & 0.017 \\
\hline Isoleucine & $0.67^{b}$ & 0.016 & $0.61^{c}$ & 0.014 & $0.66^{\mathrm{b}}$ & 0.014 \\
\hline
\end{tabular}

$\mathrm{a}, \mathrm{b}, \mathrm{c}$ Mean values within a row or column not sharing a common superscript were significantly different $(P<0.05)$.

* $\mathrm{N}$ retained $=\mathrm{N}$ intake $-($ urinary $\mathrm{N}+$ faecal $\mathrm{N}) ; \mathrm{N}$ digested $=\mathrm{N}$ intake - faecal $\mathrm{N}$. †See Table 1.

Compared with the control diet $\mathrm{N}$ utilization was significantly $(P<0.05)$ and almost equally decreased by the $20 \%$ reductions of isoleucine, valine or methionine (Table 4). Additions of leucine or BCAA to the balanced control diet had no significant effect on $\mathrm{N}$ utilization. Adding leucine to an isoleucine-limiting diet decreased $\mathrm{N}$ utilization significantly $(P<0 \cdot 05)$. This was reversed by the simultaneous addition of valine. Addition of leucine to the valinelimiting diet tended to reduce $\mathrm{N}$ retention and utilization, a tendency which was reversed by the simultaneous addition of isoleucine: however, these effects were not significant.

In contrast, adding either leucine alone or all three BCAA to a methionine-limiting diet, significantly $(P<0.05)$ increased $\mathrm{N}$ utilization.

\section{Discussion}

$\mathrm{N}$ utilization was similarly reduced by the $20 \%$ reductions in the dietary concentrations of valine, isoleucine or methionine. Therefore, it can be concluded that these diets were equally deficient in their specific limiting amino acid. Consequently any change in $\mathrm{N}$ utilization should reflect a change in utilization of the limiting amino acid.

\section{Valine- and isoleucine-deficient diets}

Because the BCAA interact with each other the reduction in utilization of $\mathrm{N}$ due to excess leucine in a diet limiting in isoleucine was to be expected. This observation may be explained if significant amounts of isoleucine are lost via catabolic processes activated by excess leucine. Assuming that leucine excess increases the catabolism of valine and isoleucine in the pig in the same way as in chicks, rats and human subjects (Calvert et al. 1982; Meguid et al. 1983; Block \& Harper, 1984), increased catabolism of valine or isoleucine would have reduced the utilization of these amino acids resulting in reduced utilization of dietary $\mathrm{N}$.

The present findings show that isoleucine-limiting diets were more affected by an excess of leucine than valinelimiting diets, indicating that leucine affected the utilization of isoleucine more than that of valine. Benton et al. (1956) came to a similar conclusion using growing rats. In contrast, results of an experiment with young chicks suggest that the leucine-valine interaction seems to be more potent than the interaction between leucine and isoleucine (D'Mello \& Lewis, 1970). The reason why the two species responded differently is not known.

The observation that, with isoleucine-deficient diets, addition of valine reversed the effect of excess leucine can be explained by competition between their keto acids for decarboxylation via BCKDH. In the rat it has been shown that $\alpha$-ketoisovaleric and $\alpha$-keto- $\beta$-methyl-n-valeric acids have similar $K_{\mathrm{m}}$ values (Parker \& Randle, 1978; Boyer \& Odessey, 1990) and compete as substrates for BCKDH. Hence, when an alternative substrate is provided, competition between the keto acid of the amino acid in excess and the keto acid of the limiting amino acid may reduce the oxidation of the limiting amino acid and lead to increased $\mathrm{N}$ utilization.

\section{Methionine-deficient diets}

Somewhat surprisingly, excess leucine as well as excess BCAA enhanced $\mathrm{N}$ retention in pigs given diets limiting in methionine. It appears that excesses of BCAA in methionine-limiting diets have the effect of sparing methionine. The increased protein accretion could be the result of either increased protein synthesis or decreased protein degradation or both. Leucine and $\alpha$-ketoisocaproic acid have been shown in vitro to increase protein synthesis in rat muscle (Fulks et al. 1975; Li \& Jefferson, 1978) and also appear to reduce muscle protein degradation (Goldberg \& Tischler, 1981). Although there is in vitro evidence that leucine alters protein synthesis, the in vivo effect, with amino-acid-adequate diets, is questionable (McNurlan et al. 1982, 1983).

Another possible way in which leucine or BCAA might interact with methionine catabolism is through the $\mathrm{BCKDH}$ complex which catabolizes branched-chain keto acids and also $\alpha$-ketobutyric acid and $\alpha$-keto- $\gamma$-methiolbutyric acid, keto acids produced from methionine. Benevenga \& Haas (1986) reported that the pig is capable of oxidizing methionine via the transamination pathway in liver mitochondria. In the rat, excess leucine or other BCAA seems to increase the catabolism of their keto acids (Block \& Harper, 1984; Block et al. 1985) which would lead to a greater rather than lower oxidation of methionine. However, it may be that the provision by the amino acid in excess of an alternative substrate at a higher concentration actually diminishes the oxidation of the limiting amino acid. It is not known whether BCKDH in pig tissues can be activated by excesses of leucine or BCAA, or whether leucine excess alters keto acid concentrations in pigs to the same extent as in rats. It also seems necessary to consider whether methionine is catabolized via the transamination pathway in the pig under the conditions of the present experiment when methionine was limiting. These issues are examined in the following paper (Langer et al. 2000).

\section{Non-deficient diets}

Unlike their effects with the methionine-limiting diet, excesses of leucine or BCAA added to the balanced control diet did not significantly alter $\mathrm{N}$ retention. As there would be 
competition for intestinal transport amongst the BCAA with the balanced diets, as with the imbalanced ones, this seems to support the suggestion that in post-absorptive metabolism these interactions exert their effects on $\mathrm{N}$ retention. Thus, under these conditions, moderate excesses of BCAA appeared to have little, if any, effect on the utilization of other amino acids. However, because the control diet was designed to be ideally balanced, it is also possible that a potential positive effect could have been limited by one or more of the other indispensable amino acids. When methionine was limiting all other indispensable amino acids were in relative excess and any increase in methionine utilization could be expressed as increased body protein accretion but when, in the control diet, all amino acids were equally limiting, improvement in the utilization of any one would not result in increased $\mathrm{N}$ retention unless there was a simultaneous improvement in the utilization of all the others.

\section{Acknowledgements}

This work was supported by the Scottish Office Agriculture, Environment and Fisheries Department and the financial support (S.L.) of Eurolysine SA and Degussa AG is gratefully acknowledged. We are also grateful to Dr M. Franklin and the staff of BioSS for their help with the statistical analyses and to Mrs Ann White for her help with the preparation of the manuscript.

\section{References}

Aftring RP, Block KP \& Buse MG (1986) Leucine and isoleucine activate skeletal muscle branched-chain $\alpha$-keto acid dehydrogenase in vivo. American Journal of Physiology 250, E599-E604.

Bech-Andersen S, Mason VC \& Dhanoa MS (1990) Hydrolysate preparation for amino acid determinations in feed constituents. 9. Modifications to oxidation and hydrolysis conditions for streamlined procedures. Journal of Animal Physiology and Animal Nutrition 63, 188-197.

Benevenga NJ (1984) Evidence for alternative pathways of methionine catabolism. In Advances in Nutritional Research, vol. 6, pp. 1-18 [HH Draper, editor]. New York, NY: Plenum Press.

Benevenga NJ \& Haas LG (1986) Isolation and identification of 3-methylthiopropionyl-CoA (MTP-CoA) and methanethiol from metabolism of $\alpha$-keto- $\gamma$-methiolthiobutyrate (keto-met) and 3-methylthiopropionate (MTP) by pig liver mitochondria. Journal of Nutrition 116, XXIV, Abstr. 24

Benton DA, Harper AE, Spivey HE \& Elvehjem CA (1956) Leucine, isoleucine and valine relationships in the rat. Archives of Biochemistry and Biophysics 60, 147-155.

Block KP (1989) Interactions among leucine, isoleucine, and valine with special reference to the branched-chain amino acid antagonism. In Absorption and Utilization of Amino Acids, vol. 1, pp. 229-244 [M Friedman, editor]. Boca Raton, FL: CRC Press.

Block KP \& Harper AE (1984) Valine metabolism in vitro: effects of high dietary levels of leucine and isoleucine. Metabolism 33, 559-566.

Block KP \& Harper AE (1991) High levels of dietary amino and branched-chain $\alpha$-keto acids alter plasma and brain amino acid concentrations in rats. Journal of Nutrition 121, 663-671.

Block KP, Soemitro S, Heywood BW \& Harper AE (1985)
Activation of liver branched-chain $\alpha$-keto acid dehydrogenase in rats by excesses of dietary amino acids. Journal of Nutrition 115, 1550-1561.

Boyer B \& Odessey R (1990) Quantitative control analysis of branched-chain 2-oxo acid dehydrogenase complex activity by feedback inhibition. Biochemical Journal 271, 523-528.

Calvert CC, Klasing KC \& Austic RE (1982) Involvement of food intake and amino acid catabolism in the branched-chain amino acids antagonism in chicks. Journal of Nutrition 112, 627-635.

Davidson J, Mathieson J \& Boyne AW (1970) The use of automation in determining nitrogen by the Kjeldahl method, with final calculation by computer. Analyst 95, 181-193.

D'Mello JPF \& Lewis D (1970) Amino acid interactions in chick nutrition. 2. Interrelationships between leucine, isoleucine and valine. British Poultry Science 11, 313-323.

Frick GP, Tai L-R, Blinder L \& Goodman HM (1981) L-Leucine activates branched chain $\alpha$-keto acid dehydrogenase in rat adipose tissue. Journal of Biological Chemistry 256, 2618-2620.

Fulks RM, Li JB \& Goldberg AL (1975) Effects of insulin, glucose, and amino acids on protein turnover in rat diaphragm. Journal of Biological Chemistry 250, 290-298.

Fuller MF, Livingstone RM, Baird BA \& Atkinson T (1979) The optimal amino acid supplementation of barley for the growing pig. 1. Response of nitrogen metabolism to progressive supplementation. British Journal of Nutrition 41, 321-331.

Goldberg AL \& Tischler ME (1981) Regulatory effects of leucine on carbohydrate and protein metabolism. In Metabolism and Clinical Implications of Branched Chain Amino and Ketoacids, pp. 205-216 [M Walser and JR Williamson, editors]. New York, NY: Elsevier, North-Holland.

Harper AE, Benevenga NJ \& Wohlhueter RM (1970) Effects of ingestion of disproportionate amounts of amino acids. Physiological Reviews 50, 428-558.

Harper AE, Block KP \& Cree TC (1983) Branched-chain amino acids: Nutritional and metabolic interrelationships. In Proceedings of the IVth Symposium on Protein Metabolism and Nutrition, Clermont-Ferrand (France), European Association of Animal Production Publication no. 31, vol. 1, pp. 159-181 [R Pion, M Arnal and D Bonin, editors]. Paris: INRA.

Henry Y, Duée PH \& Rérat A (1976) Isoleucine requirement of the growing pig and leucine-isoleucine interrelationship. Journal of Animal Science 42, 357-364.

Langer S \& Fuller MF (1994) The effect of excessive amounts of branched-chain amino acids on amino acid utilization in growing pigs. Proceedings of the Nutrition Society 53, 108A.

Langer S, Scislowski PWD, Brown DS, Dewey P \& Fuller MF (2000) Interactions among the branched-chain amino acids and their effects on methionine utilization in growing pigs: effects on plasma amino- and keto-acid concentrations and branched-chain keto-acid dehydrogenase activity. British Journal of Nutrition 83, 49-58.

Li JB \& Jefferson LS (1978) Influence of amino acid availability on protein turnover in perfused skeletal muscle. Biochimica et Biophysica Acta 544, 351-359.

Livesey G (1981) Metabolism of 'essential' 2-oxo acids by liver and a role for branched-chain oxo acid dehydrogenase in the catabolism of methionine. In Metabolism and Clinical Implications of Branched Chain Amino and Ketoacids, pp. 143-148 [M Walser and JR Williamson, editors]. New York, NY: Elsevier, North-Holland.

McNurlan MA, Fern EB \& Garlick PJ (1982) Failure of leucine to stimulate protein synthesis in vivo. Biochemical Journal 204, 831-838.

McNurlan MA, Fern EB \& Garlick PJ (1983) The effect of high doses of leucine on the protein synthesis in rat tissues. In Amino Acids. Metabolism and Medical Applications, pp. 188-191 
[GL Blackburn, JP Grant and VR Young, editors]. Boston, MA: John Wright and Sons.

Meguid MM, Schwarz HP, Matthews DE, Karl IE, Young VR \& Bier DM (1983) In vivo and in vitro branched-chain amino acid interactions. In Amino Acids. Metabolism and Medical Applications, pp. 147-154 [GL Blackburn, JP Grant and VR Young, editors]. Boston, MA: John Wright and Sons.

Naumann C \& Vassler R (1993) Methodenbuch (Band III) Die chemische Untersuchung von Futtermitteln. Darmstadt: VDLUFA-Verlag.

Oestemer GA, Hanson LE \& Meade RJ (1973) Leucine-isoleucine interrelationship in the young pig. Journal of Animal Science 36, 674-678.

Parker PJ \& Randle PJ (1978) Inactivation of rat heart branched-chain 2-oxo acid dehydrogenase complex by adenosine triphosphate. FEBS Letters 95, 153-156.

Tannous RI, Rogers QR \& Harper AE (1966) Effect of leucineisoleucine antagonism on the amino acid pattern of plasma and tissues of the rat. Archives of Biochemistry and Biophysics 113, $356-361$.

Taylor AJ, Cole DJA \& Lewis D (1984) Amino acid requirements of growing pigs. 5. The interactions between isoleucine and leucine. Animal Production 38, 257-261.

Wang TC \& Fuller MF (1989) The optimum dietary amino acid pattern for growing pigs. 1. Experiments by amino acid deletion. British Journal of Nutrition 62, 77-89.

Wang TC \& Fuller MF (1990) The effect of the plane of nutrition on the optimum dietary amino acid pattern for growing pigs. Animal Production 50, 155-164. 